\title{
A Hybrid Method to Shorten Congestion and Implement Data Guarantee in Cloud Computing
}

\author{
P.Nandhini, K. Shanmuga Priya, I. Mary Linda
}

\begin{abstract}
Distributed computing is used any place in light of the way that it gives on solicitation access of advantages and reduces cost, it offers dynamic task of benefits for guaranteed and trustworthy organizations. Customers store their data on a single virtual server, when customer needs to get to any data that data might be changed or balanced by unapproved people for malevolent reason since customer's don't have organize control of data So security is a noteworthy test for dispersed registering, to improve the immovable nature of organizations it is imperative to assemble the security level in the cloud where the customer should free from dependability, approval, rightness or protection. In this paper, I proposed another system for blockage control and data security in circulated figuring. Various makers have given their considerations on data security in cloud anyway no one gives the full control to the customer. This methodology control stop up by diminishing the proportion of data. In the present system cloud pro center uses weight strategy to diminish the degree of data after that scramble data that fabricates the proportion of ciphertext interestingly with compacted data. Another encryption framework is used to encode the pressed data that does not assemble the range of ciphertext. There are two rule ideal conditions of this methodology (I) it doesn't fabricate the range of ciphertext connection with existing strategy and (ii) reduce the blockage among server and customer by speedy transmission. In case we decline the range of data then data would be traded among customer and server in less proportion of time so for this circumstance this technique controls the blockage among customer and server.
\end{abstract}

Keywords: ciphertext, blockage control

\section{INTRODUCTION}

Distributed computing is a kind of preparing which gives the workplace to use resources open on cloud structure, in other word we can express that it is the place resources are recouped through framework, it empowers customer to use development engaged organizations through the web. Circulated processing is an electronic organization where the customer can without a doubt use limit, organizations without knowing how it is truly working inside. Disseminated registering is an aggregation of virtual machines wherein customer just uses the organizations gave by the virtual machines they don't have a control on virtual

Revised Manuscript Received on August 22, 2019.

P.Nandhini,Department of CSE,Bharath Institute of Higher Education \& Research,TamilNAdu Email: nandinisureshp@gmail.com

K. Shanmuga Priya Department of CSE,Bharath Institute of Higher Education \& Research,TamilNAdu Email: shanmugapriyabiher@gmail.com

I. Mary LindaDepartment of CSE,Bharath Institute of Higher Education \& Research,TamilNAdu Email: catchlin.18@gmail.com machines. In dispersed processing a couple of affiliations store their data on a singular virtual server sometimes different working structures are executed on a lone virtual server, for this circumstance there is chances of risk from other machine. So there is a need of unusual state security especially out in the open cloud structure. [1],[3],[5]

\section{MATERIALS AND METHODOLOGY}

There are some essential characteristics of disseminated processing:

Area Independence: it infers zone of device isn't essential for the customer where it is discovered, the customer just uses the organizations through web. They don't need to perceive what kind of device is used by customer or cloud; they simply realize how to use it. [2 ],[4],[6]

Multitenancy: it suggests a single piece of benefit is used by different customers. A singular customer is known as the occupant. So cloud gives an office to use a lone event of benefit over a broad pool of customers.

Unwavering quality: uses different overabundance (copied) goals which make it well fitting for business and catastrophe recovery. [7],[9], [10]

Estimated advantage: it infers cloud thus measures about organizations, resources used by customers and giving straightforwardness from customers.

Versatility: change of organizations quickly according to customer's essential with no issue in existing organizations. Security: in view of centralization of data security is the standard characteristics of data. It gives better security yet need to assemble the security level.

On solicitation self organization: in which customer can use the organizations as shown by their need without impedance of the expert center[13], [15],[17].

\section{PROPOSED MODEL}

\section{RESULTS}

Around there I discussed on proposed exhibit how they would be profitable for customers and pro co-op.Number juggling coding and to scramble I proposed guarantee encryption estimation (AHSP Algorithm) when we pack data then it'll decrease investigate to $20-25 \%$. The advantages of using weight framework is that ensuing to decreasing the range of data it'll take 20-25\% less extra space of cloud server, this technique saves the space of server another ideal position is whether we reduce the size then we can trade data inside less time conversely with the principal archive since channel has the compelled

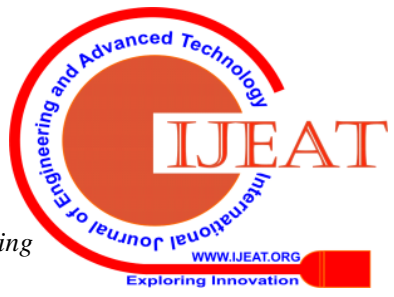


information transmission. For example: expect as far as possible is to trade data $1 \mathrm{MBPS}$, the proportion of the primary report is $10 \mathrm{MB}$ then this record would be moved in 10 seconds. In the wake of using this model, the degree of the principal record is $10 \mathrm{MB}$, size of the compacted archive is $7 \mathrm{MB}$, and now this record would be moved in 7 seconds. Right when report would be traded inside 7 second then it reduces the stop up on channel or between cloud server and customer since cloud server reinforces multitenancy incorporate where a lone resource is used by various customers. In existing methodology all encryption frameworks require same of most prominent extra space for encoded data interestingly with the primary data. This model keeps more effect on greater record where it can lessen most extraordinary size. If we use both methodology then security ends up being high by then master community can give strong organization high security. [14],[16], [18]

\section{PROPOSED ALGORITHM}

This is an encryption computation performed on the customer side, when customers are allowed to get to the organizations of cloud the encryption count will performed by tapping on exchange or download get. The puzzle key should be entered by the customer. In the present encryption computation we use a turnaround system of encryption to unscramble the record, the key component of AHSP Algorithm is that there is no convincing motivation to execute/plot an unraveling estimation it unscrambles the data by a comparative technique. This count plays out a variable number of rounds depend upon the key length and in each round this estimation creates a sporadic key. It is hard to anticipate the unpredictable key in each round so this estimation gives a high security level. There are no any limitations of key length anyway the key size should be square of any number. [26],[28],[30]

The character for the ASCII estimation of newkey isn't available on support. These are the held notice picture for system so it is hard to part the new key. This technique is performed in each round of this count so keyl and newkeywould be change in each round. [19],[21], [20],

The fundamental key is should be entered from customer, it may be watchword of customer or authority association can incorporate extra catch for a secret key yet the key pro center should be clueless from puzzle key and providers need to take an interest their customer to verify data. Variable key length anyway length should be square of any entire number. In case we use the best length of the key then it is increasingly secure in light of the fact that for most extraordinary key length there would be the best number of rounds which keeps customer's data secure from unapproved customer. Like existing encryption count AHSP Algorithm doesn't require . [23],[22], [24]

\section{CONCLUSION}

Security of set away data is a noteworthy test for cloud authority association, on circulated registering customers simply get to their data and use the organization gave by the expert center, customers know nothing about its security and don't have any control on their data. Subsequently, in this paper we proposed our new count to offer control to customers for their data security. From the above case and Table1 we separated that this count gives better security and moreover gives full control to customers. This paper similarly shows the blend appear for cloud in this model two extraordinary frameworks are used weight and encryption. For weight I used the present methodology and to scramble I used case encryption computation. We understand that cloud server contains very titanic proportion of data and diverse customer gets to a cloud server meanwhile so this cross breed show decrease the degree of data that extras the extra space of cloud server and addition throughput of dispersed registering. Finally after all preliminary we found that AHSP Algorithm gives better security which is constrained by the customers itself. [25],[27],[29]

\section{REFERENCES}

1. Gowri Sankaran, B., Karthik, B. \& Vijayaragavan, S.P. 2019, "Weigh ward change region plummeting change for square based image huffman coding", International Journal of Innovative Technology and Exploring Engineering, vol. 8, no. 10, pp. 4313-4316.

2. Gowri Sankaran, B., Karthik, B. \& Vijayaragavan, S.P. 2019, "Image compression utilizing wavelet transform", International Journal of Innovative Technology and Exploring Engineering, vol. 8, no. 10, pp. 4305-4308.

3. Kandavel, N. \& Kumaravel, A. 2019, "Offloading computation for efficient energy in mobile cloud computing", International Journal of Innovative Technology and Exploring Engineering, vol. 8, no. 10, pp. 4317-4320.

4. Vinoth, V.V. \& Kanniga, E. 2019, "Reversible data hiding in encrypting images-an system", International Journal of Engineering and Advanced Technology, vol. 8, no. 6, pp. 3051-3053.

5. Selvapriya, B. \& Raghu, B. 2019, "Pseudocoloring of medical images: A research", International Journal of Engineering and Advanced Technology, vol. 8, no. 6, pp. 3712-3716.

6. Senthil Kumar, K. \& Muthukumaravel, A. 2019, "Bi-objective constraint and hybrid optimizer for the test case prioritization", International Journal of Engineering and Advanced Technology, vol. 8, no. 6, pp. 3436-3448.

7. Kavitha, G., Priya, N., Anuradha, C. \& Pothumani, S. 2019, "Read-write, peer-to-peer algorithms for the location-identity split", International Journal of Innovative Technology and Exploring Engineering, vol. 8 , no. 9 Special Issue 3, pp. 445-447.

8. Kaliyamurthie, K.P., Michael, G., Anuratha, C. \& Sundaraj, B. 2019 "Certain improvements in alzheimer disease classification using nove fuzzy c means clustering for image segmentation", International Journal of Innovative Technology and Exploring Engineering, vol. 8, no. 9 Special Issue 3, pp. 599-604.

9. Kaliyamurthie, K.P., Sundarraj, B., Geo, A.V.A. \& Michael, G. 2019, "RIB: Analysis of I/O automata", International Journal of Innovative Technology and Exploring Engineering, vol. 8, no. 9 Special Issue 3 , pp. 1019-1022.

10. Velvizhi, R., Rajabhushanam, C. \& Vidhya, S.R.S. 2019, "Opinion mining for travel route recommendation using Social Media Networks (Twitter)", International Journal of Innovative Technology and Exploring Engineering, vol. 8, no. 9 Special Issue 3, pp. 508-512.

11. Kavitha, R., Sangeetha, S. \& Varghese, A.G. 2019, "Human activity patterns in big data for healthcare applications", International Journal of Innovative Technology and Exploring Engineering, vol. 8, no. 9 Special Issue 3, pp. 1101-1103.

12. Pothumani, S., Anandam, A.K., Sharma, N. \& Franklin, S. 2019, "Extended VEOT framework - Implemented in a smart boutique", International Journal of Innovative Technology and Exploring Engineering, vol. 8, no. 9 Special Issue 3, pp. 762-767.

13. Kaliyamurthie, K.P., Michael, G., Krishnan, R.M.V. \& Sundarraj, B. 2019, "Pseudorandom techniques for the internet", International Journal of Innovative Technology and Exploring Engineering, vol. 8, no. 9 Special Issue 3, pp. 915-918.

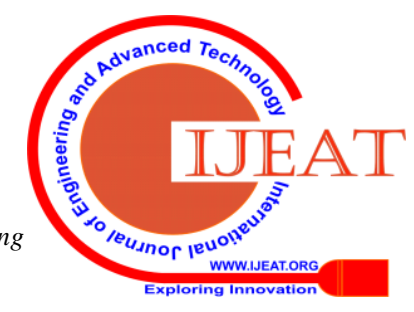


14. Aravindasamy, R., Jeffrin Rajan, M., Rama, A. \& Kavitha, P. 2019 "Deep learning provisions in the matlab: Focus on CNN facility", International Journal of Innovative Technology and Exploring Engineering, vol. 8, no. 9 Special Issue 3, pp. 990-994.

15. Theivasigamani, S., Linda, M. \& Amudha, S. 2019, "Object sensing and its identification \& motion sensing", International Journal of Innovative Technology and Exploring Engineering, vol. 8, no. 9 Special Issue 3, pp. 545-549.

16. Mary Linda, I., Vimala, D. \& Shanmuga Priya, K. 2019, "A methodology for the emulation of IPv4", International Journal of Innovative Technology and Exploring Engineering, vol. 8, no. 9 Special Issue 3, pp. 848-852.

17. Velvizhi, R., Priya, D.J., Vimala, D. \& Linda, I.M. 2019, "Increased routing algorithm for mobile adhoc networks", International Journal of Innovative Technology and Exploring Engineering, vol. 8, no. 9 Special Issue 3, pp. 1606-1608.

18. Sangeetha, S., Anuradha, C. \& Priya, N. 2019, "DNS in real world", International Journal of Innovative Technology and Exploring Engineering, vol. 8, no. 9 Special Issue 3, pp. 937-940.

19. Geetha, C., Vimala, D. \& Priya, K.S. 2019, "Constructing multi-processors and spreadsheets with SKIVE", International Journal of Innovative Technology and Exploring Engineering, vol. 8, no. 9 Special Issue 3, pp. 516-519.

20. Yugendhar, K., Sugumar, V. \& Kavitha, P. 2019, "A novel method of univac using fuzzy logic", International Journal of Innovative Technology and Exploring Engineering, vol. 8, no. 9 Special Issue 3, pp. 435-437.

21. Kaliyamurthie, K.P., Michael, G., Elankavi, R. \& Jijo, S.A. 2019 "Implementing aggregate-key for sharing data in cloud environment using cryptographic encryption", International Journal of Innovative Technology and Exploring Engineering, vol. 8, no. 9 Special Issue 3 , pp. 957-959.

22. Jeffrin Rajan, M., Aravindasamy, R., Kavitha, P. \& Rama, A. 2019, "A novel method of object orientation variation in $\mathrm{C}++$ and java", International Journal of Innovative Technology and Exploring Engineering, vol. 8, no. 9 Special Issue 3, pp. 708-710.

23. Nayak, R., Dinesh, S. \& Thirunavukkarasu, S. 2019, "A novel method improvement of rapid miner for the data mining applications", International Journal of Innovative Technology and Exploring Engineering, vol. 8, no. 9 Special Issue 3, pp. 457-460.

24. Sivaraman, K., Krishnan, R.M.V., Sundarraj, B. \& Sri Gowthem, S. 2019, "Network failure detection and diagnosis by analyzing syslog and SNS data: Applying big data analysis to network operations", International Journal of Innovative Technology and Exploring Engineering, vol. 8, no. 9 Special Issue 3, pp. 883-887.

25. Vimala, D., Linda, I.M. \& Priya, K.S. 2019, "Decoupling online algorithms from erasure coding in DNS", International Journal of Innovative Technology and Exploring Engineering, vol. 8, no. 9 Special Issue 3, pp. 950-953.

26. Rama, A., Kumaravel, A. \& Nalini, C. 2019, "Preprocessing medical images for classification using deep learning techniques", International Journal of Innovative Technology and Exploring Engineering, vol. 8, no. 9 Special Issue 3, pp. 711-716.

27. Sangeetha, S., Srividhya, S.R., Anita Davamani, K. \& Amudha, S. 2019, "A procedure for avoid overrun error in universal synchronous asynchronous receiver transmitter (usart) by utilizing dummy join and interrupt latency method", International Journal of Innovative Technology and Exploring Engineering, vol. 8, no. 9 Special Issue 3, pp. 657-660.

28. Aravindasamy, R., Jeyapriya, D., Sundarajan, B. \& Sangeetha, S. 2019, "Data duplication in cloud for optimal performance and security", International Journal of Innovative Technology and Exploring Engineering, vol. 8, no. 9 Special Issue 3, pp. 1156-1158.

29. Aravindasamy, R., Jeffrin Rajan, M., Sugumar, V. \& Kavitha, P. 2019, "A novel method on developing superblocks and the transistor using apodryal", International Journal of Innovative Technology and Exploring Engineering, vol. 8, no. 9 Special Issue 3, pp. 982-985.

30. Sasikumar, C.S. \& Kumaravel, A. 2019, "E-learning attributes selection through rough set theory and data mining", International Journal of Innovative Technology and Exploring Engineering, vol. 8, no. 10, pp. 3920-3924.

\section{AUTHORS PROFILE}

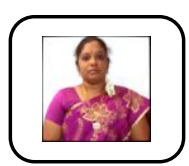

P.Nandhini Assistant Professor,Department of CSE,Bharath Institute of Higher Education \& Research,TamilNAdu

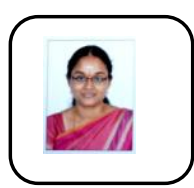

K. Shanmuga Priya Assistant Professor,Department of CSE,Bharath Institute of Higher Education \& Research,TamilNAdu

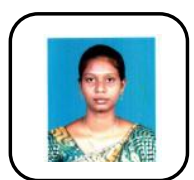

I. Mary Linda, Assistant Professor,Department of CSE,Bharath Institute of Higher Education \& Research,TamilNAdu 